\title{
An Autoimmune Haemolytic Anaemia Secondary to Ipilimumab Treatment
}

\section{Autoimunní hemolytická anémie způsobená léčbou ipilimumabem}

\author{
Ramos B., Gastal G., Rovere R. K. \\ Department of Internal Medicine and Medical Oncology, Hospital Santo Antonio, Blumenau, Santa Catarina, Brazil
}

\begin{abstract}
Summary
Background: Melanoma is one of the fastest growing neoplasms worldwide. Treatment of metastatic disease has swiftly shifted in the last decade from generally ineffective chemotherapy regimens to highly effective targeted treatments or immunotherapy, with a range of side effects that differ completely from those of previous treatments for this disease. Case: We present a case of a 71-year-old man with diagnosis metastatic melanoma. This patient was treated with anti-CTLA-4 antibody ipilimumab. Despite minor skin toxicity, the regimen was well tolerated until he developed hemolytic anemia, an autoimmune side effect of ipilimumab. The treatment was withdrawn and steroids were administered until the issue was resolved. Conclusion: Immunotherapy has become the standard of care for many tumors, and its side effects are completely different from those of chemotherapy, meaning that oncologists must be aware of this to avoid a potentially life-threatening situation and arrive at an early diagnosis and implement prompt treatment.
\end{abstract}

\section{Key words}

anemia - autoimmune event - anti-CTLA-4

\section{Souhrn}

Úvod: Melanom je jedním z nejrychleji rostoucích nádorů po celém světě. V posledních 10 letech se léčba metastatického melanomu rychle přesunula od obecně neúčinné chemoterapie k vysoce účinným cíleným terapiím nebo k imunoterapii, s řadou vedlejších účinků, které jsou zcela jiné, než u dřive použivaných postupů. Případ: Prezentujeme prípad 71letého muže s diagnózou metastatického melanomu. Tento pacient byl léčen protilátkou anti-CTLA-4 ipilimumabem. Navzdory menší toxicitě kưže byl tento režim dobře tolerován, dokud se nerozvinula hemolytická anémie, jako autoimunitní vedlejší účinek způsobený ipilimumabem. Léčba byla zastavena a byly nasazeny steroidy do vyřešení problému. Závěr: Imunoterapie se stala standardem péče pro mnohé nádory, ale vedlejší účinky této léčby jsou zcela odlišné od chemoterapie. To znamená, že onkologové musí dávat větší pozor, protože časná diagnóza a okamžitá léčba může zachraňovat život.

\section{Klíčová slova}

anémie - autoimunitní událost - anti-CTLA-4
The authors declare they have no potential conflicts of interest concerning drugs, products, or services used in the study.

Autoři deklarují, že v souvislosti s předmětem studie nemají žádné komerční zájmy.

The Editorial Board declares that the manuscript met the ICMJE recommendation for biomedical papers.

Redakční rada potvrzuje, že rukopis práce splnil ICMJE kritéria pro publikace zasílané do biomedicínských časopisů.

\section{$\Xi^{\circ}$}

Rodrigo Kraft Rovere, MD

Oncology Unit

Santo Antonio Hospital

Rua Itajai 54

Blumenau, Santa Catarina

CEP 89050100, Brazil

e-mail: rodrigorovere@hotmail.com

Submitted/Obdrženo: 12.1.2017

Accepted/Prijato: 1. 2. 2017

doi: 10.14735/amko2017128 
A 71-year-old male presented with an ulcerated lesion on the right hallux, skin nodules on the right leg and a right inguinal mass in September 2014. Incisional biopsy revealed an undifferentiated epithelioid cell malignant neoplasm. Immunohistochemistry favored the diagnosis of melanoma, with positivity for $\mathrm{S} 100$ and A103 and negativity for cytokeratins. $B R A F$ mutation analysis was negative.

${ }^{18} \mathrm{~F}$-FDG-PET-Scan in 10/11/2014 demonstrated anomalous enhancing in a $15 \mathrm{~mm}$ right external iliac lymph node, a large right inguinal mass $(21 \times 4.5 \times 6 \mathrm{~cm})$, a subcutaneous nodule in the right leg $(9 \mathrm{~mm})$ and the right hallux lesion. CT scan showed two non-enhancing suspicious lung nodules ( 6 and $8 \mathrm{~mm}$ resp.).

In January 2015, the patient initiated palliative chemotherapy with dacarbazine $250 \mathrm{mg} / \mathrm{m}^{2}$ from days 1 to 5 each 28 days, while awaiting for approval of ipilimumab (Yervoy ${ }^{\circledast}$ ). He had a MRI-confirmed reduction in the inguinal mass after four cycles of dacarbazine.

Ipilimumab was then started at the standard dose of $3 \mathrm{mg} / \mathrm{kg}$ each 3 weeks, and after four cycles (24/06/2015), he had additional decrease in the inguinal mass, while chest CT evidenced stable lung nodules, suggestive of granulomas.

He was reevaluated by the surgical oncologist who performed a complete resection of the remaining lesions (right hallux, satellite nodules and iliac mass and lymph nodes) in 24/08/2015. He was treated with a 14-day parenteral antibiotic course after surgery due to surgical site infection. After recovery, he received $44 \mathrm{~Gy}$ of adjuvant radiation to the groin and pelvic region until January 2016.

In 27/05/2016, he visited the emergency department due to an increasing asthenia in the preceding couple weeks. Physical exam revealed pallor and jaundice, with a normal cardiopulmonary evaluation and no hepatosplenomegaly.

Laboratory revealed a slightly macrocytic anemia, with normal leukocyte and platelet counts. Liver function tests and vitamin $B_{12}$ levels were normal, but lactate dehydrogenase and indirect bilirubin levels were high, raising suspicion of hemolytic anemia.

Further testing revealed a low haptoglobin level, positive direct Coombs test
(IgG and monoclonal C3d) and elevated reticulocyte count. Antinuclear and anti-DNA antibodies were negative, and urine and serum protein electrophoresis were normal.

There was no history of medication use or respiratory, urinary or gastrointestinal infections in the preceding 4 months.

Chest and abdominal computed tomography were normal, as well as the upper endoscopy and colonoscopy.

Bone marrow biopsy revealed an erythroid hyperreactive marrow, excluding aplastic anemia.

He was started on daily prednisolone at $1 \mathrm{mg} / \mathrm{kg}$, and a rise in erythrocyte count ensued in two weeks. Steroids were maintained for eight weeks, with normalization of blood and reticulocyte counts and bilirubin and lactate dehydrogenase levels. Subsequently, the steroids were gradually tapered.

\section{Discussion}

Treatment with immune checkpoint inhibitors is associated with toxicity distinct from that seen with cytotoxic chemotherapy, the so-calledimmune-related adverse events (irAEs) [1-9]. Interest in the prevalence, detection and management of such phenomena is growing, consonant with the rise in prescriptions of these medications.

Ipilimumab is an antibody that targets and inhibits the immune checkpoint called cytotoxic T-lymphocyte associated antigen 4 (CTLA-4), resulting in T-cell activation and proliferation and enhancing the host's antitumor response [3,4,7-12]. It has been approved for the treatment of unresectable metastatic melanoma since $2011[2,3,12]$, being the first therapy to actually prolong survival in these patients $[1,2,5,7-9,11,12]$.

With standard dosage, serious (CTCAEs grade 3 or higher) adverse events occur in approximately $15-20 \%$ of patients, mostly dermatologic, gastrointestinal, hepatic or endocrine $[1-4,6,8,9]$. Hematologic events are uncommon [1,5,6, $10,13]$, even with higher doses in recent adjuvant trials $[3,4,7,11]$. There are two case reports of ipilimumab-associated anemia with red cell aplasia $[10,13]$, and only one case of autoimmune hemolytic anemia [5].

Hemolytic anemia needs to be considered in any patient with pallor and jaundice, especially if accompanied by macrocytic anemia and indirect bilirubinemia. High LDH and haptoglobin and reduced haptoglobin corroborate and positivity in either direct Coombs or anti-C3d confirms the diagnosis. In a minority of cases, an associated disorder can be present, mainly viral infections, autoimmune disorders (mainly lupus), lymphoproliferative disorders, certain drugs and blood transfusions [14].

Management of irAEs involves, depending on the grade of the event, discontinuing of the drug and steroid usage (event. other immunosupressors in rare cases), overlapping with the treatment recommendations of autoimmune hemolytic anemia [14]. Mild and early toxicity can be completely reverted, as happened to our patient [1,3-5].

\section{References}

1. Champiat S, Lambotte O, Barreau E et al. Management of immune checkpoint blockade dysimmune toxicities: a collaborative position paper. Ann Oncol 2016; 27(4): 559-574. doi: 10.1093/annonc/mdv623.

2. Tarhini A. Immune-mediated adverse events associated with ipilimumab CTLA-4 blockade therapy: the underlying mechanisms and clinical management. Scientifica (Cairo) 2013; 2013: 857519. doi: 10.1155/2013/857 519.

3. Weber JS, Kähler KC, Hauschild A. Management of immune-related adverse events and kinetics of response with ipilimumab. J Clin Oncol 2012; 30(21): 2691-2697. doi: 10.1200/JCO.2012.41.6750.

4. Weber J. Review: anti-CTLA-4 antibody ipilimumab: case studies of clinical response and immune-related adverse events. Oncologist 2007; 12(7): 864-872. doi: 10.1634/theoncologist.12-7-864

5. Simeone E, Grimaldi AM, Esposito A et al. Serious haematological toxicity during and after ipilimumab treatment: a case series. J Med Case Rep 2014; 8(1): 240. doi: 10.1186/1752-1947-8-240

6. Weber JS, Yang JC, Atkins MB et al. Toxicities of immunotherapy for the practitioner. J Clin Oncol 2015; 33(18): 2092-2099. doi: 10.1200/JCO.2014.60.0379.

7. Robert C, Thomas L, Bondarenko I et al. Ipilimumab plus dacarbazine for previously untreated metastatic melanoma. N Engl J Med 2011; 364(26): 2517-2526. doi: 10.1056/NEJMoa1104621.

8. Kopecký J, Trojanová P, Kubeček O et al. Treatment possibilities of ipilimumab-induced thrombocytopenia case study and literature review. Jpn J Clin Oncol 2015; 45(4): 381-384. doi: 10.1093/jjco/hyu222

9. Hodi FS, O'Day SJ, McDermott DF et al. Improved survival with ipilimumab in patients with metastatic melanoma. N Engl J Med 2010; 363(8): 711-723. doi: 10.1056/NEJMoa1003466.

10. Gordon IO, Wade T, Chin K et al. Immune-mediated red cell aplasia after anti-CTLA-4 immunotherapy 
for metastatic melanoma. Cancer Immunol Immunother 2009; 58(8): 1351-1353. doi: 10.1007/s00262-008-06 $27-x$

11. Eggermont AM, Chiarion-Sileni V, Grob JJ et al. Adjuvant ipilimumab versus placebo after complete resection of high-risk stage III melanoma (EORTC 18071): a randomised, double-blind, phase 3 trial. Lancet Oncol 2015; 16(5): 522-530. doi: 10.1016/S1470-2045(15)70 122-1.

12. Sondak VK, Smalley KS, Kudchadkar R et al. Ipilimumab. Nat Rev Drug Discov 2011; 10(6): 411-412. do: 10.1038/nrd3463.
13. Nair R, Gheith S, Nair SG. Immunotherapy-associated hemolytic anemia with pure red-cell aplasia. N Engl J Med 2016; 374(11): 1096-1097. doi: 10.1056/NEJMc1509362.

14. Gehrs BC, Friedberg RC. Autoimmune hemolytic anemia. Am J Hematol 2002; 69(4): 258-271. doi: 10.1002/ajh.10062. 